\title{
Effects of chronic obstructive pulmonary disease on morbidity and mortality after mitral valve surgery
}

\author{
Kronik obstrüktif akciğer hastalığının mitral kapak cerrahisi sonrası \\ morbidite ve mortaliteye etkisi
}

\author{
Ayten Saraçoğlu ${ }^{1}$ Yasemen Durak Erdinç, ${ }^{2}$ Kemal Tolga Saraçoğlu, ${ }^{1}$ İbrahim Haluk Kafall ${ }^{1}$ \\ ${ }^{1}$ Department of Anesthesiology and Reanimation, Istanbul Bilim University School of Medicine, Istanbul, Turkey \\ ${ }^{2}$ Department of Cardiovascular Surgery, Istanbul Bilim University School of Medicine, Istanbul, Turkey
}

\begin{abstract}
Chronic obstructive pulmonary disease is characterized by several physiological abnormalities including mucous hypersecretion and ciliary dysfunction, airflow obstruction and hyperinflation, gas exchange abnormalities, pulmonary hypertension and systemic effects. Cardiovascular disease accounts for a significant proportion of deaths. Size of the left atrium, atrial fibrillation, ischemic heart disease and functional capacity are the factors influencing surgical outcomes. The main purpose of medical therapy is to reduce the afterload. Mortality rate is relatively higher in the patients who have pulmonary hypertension, pulmonary edema, renal failure, hepatic failure, acid and severe symptoms.

Keywords: Chronic obstructive pulmonary disease; mitral valve surgery; morbidity.
\end{abstract}

öz

Kronik obstrüktif akciğer hastalığı mukus hipersekresyonu ve silier disfonksiyon, hava akımı obstrüksiyonu ve hiperinflasyon, gaz değişim anormallikleri, pulmoner hipertansiyon ve sistemik etkiler gibi çeşitli fizyolojik anormalliklerle karakterize edilir. Kardiyovasküler hastalıklar ölüm sebeplerinin anlamlı bir bölümünü oluşturmaktadır. Sol atriyum çapı, atriyal fibrilasyon, iskemik kalp hastalığı ve fonksiyonel kapasite cerrahi sonuçları etkileyen faktörlerdendir. Medikal tedavinin temel amacı ard yükü azaltmaktır. Mortalite oranı pulmoner hipertansiyon, pulmoner ödem, renal yetmezlik, hepatik yetmezlik, asit ve ciddi belirtileri bulunan hastalarda rölatif olarak daha yüksektir.

Anahtar sözcükler: Kronik obstrüktif akciğer hastalığı; mitral kapak cerrahisi; morbidite.

\section{CHRONIC OBSTRUCTIVE PULMONARY DISEASE}

\section{Definition}

Chronic obstructive pulmonary disease (COPD), which is characterized by progressive and permanent airflow limitations, develops when genetically susceptible patients are chronically exposed to environmental factors. It generally arises through a chronic inflammatory process of exposure to harmful gas and particles, such as smoking. Inflammation may show systemic features. Comorbidities and inflammations determine the course of the disease. ${ }^{[1]}$

\section{Pathology}

Chronic obstructive pulmonary disease-specific pathology is observed in airway, lung parenchyma and pulmonary vascular bed. Chronic inflammation occurs along with inflammatory cell infiltration, and structural changes develop as a result of recurrent damage and repair mechanisms. ${ }^{[2]}$ In epithelium, squamous metaplasia and atrophy occur with a decrease in the number of ciliary cells along with an increase in the number of mucus-secreting goblet cells..$^{[3]}$ In particular, the histopathological signs of increased mucus and obliteration of the lumen of bronchi, goblet cell metaplasia, 
inflammation of the bronchial walls, peribronchial fibrosis and hypertrophy of smooth muscles and contraction are observed in peripheral airway. ${ }^{[4]} \mathrm{At}$ later stages, collagen deposition and capillary bed damage develop in lung blood vessels. Pulmonary hypertension and cor pulmonale secondary to right ventricular dysfunction develop during the final stage..$^{[5,6]}$ In COPD, inflammation, oxidative stress and proteases cause pathological changes in lungs. Structural and inflammatory cells, which play a role in inflammation, induce the release of inflammatory mediators. In COPD, the predominant inflammatory cells are neutrophils, lymphocytes, macrophages and airway epithelial cells. ${ }^{[7]}$

It has been indicated that reactive oxygen derivatives contained in cigarette smoke and released by inflammatory cells contribute to physiopathology of COPD. Increased oxidative stress may contribute to COPD pathogenesis through the mechanism including oxidation of antiproteases, such as Alpha-1-antitrypsin (AAT) and secretory leukocyte protease inhibitor, attenuation of antiproteinase defense, increase of proteolysis and direct activation of matrix metalloproteinases (MMPs).The organism attempts to minimize the effects of inhaled noxious gases and particles using proteases, such as Alpha-1-antichymotrypsin, Alpha-1-antitrypsin, Alpha-2-macroglobulin, epithelial cell-derived secretory leukocyte protease inhibitor and tissue metalloproteinase inhibitors. Detrimental effects of proteases are eliminated with antiproteases. In COPD, neutrophils produce neutrophil elastase, cathepsin $G$ and proteinase-3; macrophages produce MMP-9, macrophage elastase, cathepsin L, S; and lymphocytes produce perforin and granzyme. These proteases destroy alveolar wall elastin and collagen while increasing mucus secretion. This is called the protease-antiprotease hypothesis. Other hypothesis for the pathogenesis are the Dutch hypothesis, the British hypothesis and the autoimmunity hypothesis. ${ }^{[8]}$

\section{Pathophysiology}

Chronic obstructive pulmonary disease is characterized by some physiological abnormalities including mucous hypersecretion and ciliary dysfunction, airflow obstruction and hyperinflation, gas exchange abnormalities, pulmonary hypertension and systemic effects.
Expiratory airflow limitation is a result of the loss of alveolar epithelium handles that maintain the airway patency and decrease the driving force required for expiration flow caused by elevated airway resistance and fragmentation of elastic structure, which develop with the influence of mucosal inflammation/edema, airway remodeling, bronchial wall fibrosis and increased mucosal secretions. Air trapping and reduced inspiratory capacity are observed at rest in patients with COPD. Reduction in inspiratory capacity sustains during exercise. Such patients perform rapid shallow breathing at higher volumes. This condition leads to dyspnea, increased effort to breath, respiratory muscle fatigue and decreased exercise capacity as a result of increased oxygen consumption. Ventilation/perfusion imbalance is the most significant mechanism in development of hypoxemia in COPD. Changes in the respiratory mechanics, pulmonary hyperinflation and rapid shallow breathing may trigger impairment in gas exchange and respiratory failure. Tissue loss and destruction in pulmonary arteries, hypoxic vasoconstriction, thrombus due to increase in endothelial adhesion, and thromboembolism also affect perfusion and contribute to occurrence of hypoxia. $^{[9]}$

\section{ASSESSMENT OF COMORBIDITY}

Chronic obstructive pulmonary disease has systemic consequences. Diabetes mellitus, osteoporosis, lung cancer, anemia, skeletal muscle atrophy, cachexia, cardiovascular diseases (including ischemic heart disease, heart failure, pulmonary hypertension), metabolic syndrome, obstructive sleep apnea, depression and glaucoma are the primary comorbidities. Although the comorbidities are not correlated with COPD, they affect the course and prognosis of the disease. The increase in the incidence of comorbidities in COPD proves that COPD needs to be evaluated under a multidisciplinary approach. Cardiovascular diseases are responsible for 25\%, cancer for $30 \%$ and other comorbidities are for $30 \%$ of deaths in patients with COPD. It is a known fact that increased severity of airway obstruction is associated with increased risk for hospital admission, increased health care expenditures and increased risk of death. ${ }^{[10,11]}$ Chronic obstructive pulmonary disease and comorbidities should be addressed using a multidisciplinary 
approach. In this way, it will be possible to prevent progressive deterioration of COPD due to comorbidities and to diagnose COPD at an early stage as well as creating awareness about COPD in related disciplines.

\section{CHRONIC OBSTRUCTIVE PULMONARY DISEASE AND CARDIOVASCULAR DISEASES}

The risk of coronary artery disease, stroke and sudden death increases in COPD. Coronary artery disease and COPD share some common risk factors, such as smoking, sedentary lifestyle and advanced age. ${ }^{[12]}$ It has been established that patients with airway obstruction have a high risk of death from myocardial infarction independent of other factors. The Lung Health Study verified that lung cancer and cardiovascular diseases were the primary causes of death in patients with mild and moderate COPD. Smoking cessation has been indicated to decrease the risk for cardiovascular complications and cancer risk. Cardiovascular mortality rises by $28 \%$ for every $10 \%$ fall in forced expiratory volume-

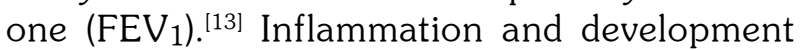
of cardiovascular pathology accelerates in end-stage COPD. ${ }^{[14]}$ Cigarette smokeinduced endothelial injury causes hypoxic vasoconstriction, vascular When pulmonary hypertension is present, even minor falls in pulmonary artery result in deterioration of gas exchange, therefore vasodilators are not recommended. ${ }^{[15]}$

\section{MITRAL VALVE DISEASE AND LUNG FUNCTIONS}

Functional changes occur in pulmonary vascular and parenchymal structures as a result of elevated left atrial pressure in patients with mitral stenosis. Ultimately, pulmonary edema due to mitral valve stenosis develops in patients causing losses in some respiratory functions. ${ }^{[16]}$ High pulmonary vascular resistance leads to arteriolar hypertrophic changes secondary to pressure. As a result, airway resistance increases, but diffusion capacity lessens. Blood flow and ventilation shift towards upper levels and ventilation rate increases. This manifestation is termed as pulmonary edema due to mitral stenosis. ${ }^{[17]}$
Obstructive and restrictive respiratory dysfunction is observed in patients with pulmonary edema due to mitral valve stenosis, and particularly small airways are affected by the condition. Chatterji et al. ${ }^{[18]}$ reported that when they measured the spirometry with echocardiography findings; they observed a small airway defect and a moderate restrictive defect in cases of mitral stenosis, directly correlated to pulmonary artery pressure, left atrial pressure, mitral valve area and transmitral gradient. Studies documented bronchial hyperactivity in mitral stenosis. Palaniswamy et al. ${ }^{[19]}$ observed a significant improvement in six minute walking distance after balloon valvotomy in patients with rheumatic mitral valve stenosis. They concluded that the improvement in dyspnea in mitral stenosis after balloon valvotomy was associated with significant improvement in airway hyper-reactivity. Inhaled corticosteroids improves bronchial hyperactivity and decreases symptoms in patients with mitral stenosis. ${ }^{[20]}$ As pulmonary venous pressure decreases in patients undergoing mitral valve replacement, lung volumes moderately improve. The most significant change is the decrease of residual volume. However, the irreversible changes induced by fibrosis and pulmonary hypertension continue and hinder complete recovery of respiratory functions. The vasoconstrictor effect disappears after mitral valve replacement. Anterior wall edema dissolves and morphological changes recover. In conclusion, pulmonary artery pressure decreases significantly in the postoperative period.

Changes occur in lung parenchyma related to transudation from pulmonary capillaries towards the interstitium and alveolar spaces. While fibrosis develops in alveolar walls, thickening is observed in the walls of pulmonary capillaries. Both the oxygen intake required for ventilation and blood gas values decrease. Then the alveolar-arterial oxygen gradient increases. ${ }^{[21,22]}$

\section{Treatment}

Although symptomatic patients with mitral stenosis have the indications for surgery, they are in general, followed under medical treatment until the New York Heart Association (NYHA) class III symptoms occur. In case of a severely dilated left atrium, atrial fibrillation and embolism, the patient should be operated on even if the patient presents only with minor symptoms. However, 
in case of mitral stenosis that does not require surgical intervention, echocardiography should be performed at regular intervals under close monitoring and time of surgery should be well established. Open or closed mitral valvotomy is a frequently preferred technique with a mortality rate of $2 \%$ in eligible patients with mitral stenosis.

Surgery is not recommended until functional problems develop in mitral insufficiency. Left ventricle function is the most efficient factor for long-term survival after surgery for patients with mitral insufficiency. Impaired left ventricle functions and decreased resistance against ejection are indicators of myocardial damage. Valve replacement is contracted in severe mitral insufficiency from end-stage dilated cardiomyopathy. Size of left atrium, atrial fibrillation, ischemic heart disease and functional capacity are the factors influencing surgical outcomes.

\section{Conclusion}

Early diagnosis of the disease is substantial not only in order to prevent the disease from progressing but also to ensure a decrease in mortality that accompany the later stages of the disease as well as reducing the direct and indirect costs of treatment. The treatment program is established with the aims of lowering risk factors and treating inflammation. In such patients, surgery is recommended after reduction of the risk through an intense medical therapy. If the patient does not respond, high-risk surgery is performed. The main purpose of medical therapy is to lessen the afterload on the heart. Mortality is relatively higher in patients that have pulmonary hypertension, pulmonary edema, renal failure, hepatic failure, acid and severe symptoms.

\section{Declaration of conflicting interests}

The authors declared no conflicts of interest with respect to the authorship and/or publication of this article.

\section{Funding}

The authors received no financial support for the research and/or authorship of this article.

\section{REFERENCES}

1. King PT. Inflammation in chronic obstructive pulmonary disease and its role in cardiovascular disease and lung cancer. Clin Transl Med 2015;4:68.
2. Kazmierczak M, Ciebiada M, Pekala-Wojciechowska A, Pawlowski M, Nielepkowicz-Gozdzinska A, Antczak A. Evaluation of Markers of Inflammation and Oxidative Stress in COPD Patients with or without Cardiovascular Comorbidities. Heart Lung Circ 2015;24:817-23.

3. Gao W, Li L, Wang Y, Zhang S, Adcock IM, Barnes PJ, et al. Bronchial epithelial cells: The key effector cells in the pathogenesis of chronic obstructive pulmonary disease? Respirology 2015;20:722-9.

4. Chung KF. The role of airway smooth muscle in the pathogenesis of airway wall remodeling in chronic obstructive pulmonary disease. Proc Am Thorac Soc 2005;2:347-54.

5. Chen W, Thomas J, Sadatsafavi M, FitzGerald JM. Risk of cardiovascular comorbidity in patients with chronic obstructive pulmonary disease: a systematic review and meta-analysis. Lancet Respir Med 2015;3:631-9.

6. Portillo K, Torralba Y, Blanco I, Burgos F, RodriguezRoisin R, Rios $\mathrm{J}$, et al. Pulmonary hemodynamic profile in chronic obstructive pulmonary disease. Int $\mathrm{J}$ Chron Obstruct Pulmon Dis 2015;10:1313-20.

7. Tetley TD. Inflammatory cells and chronic obstructive pulmonary disease. Curr Drug Targets Inflamm Allergy 2005;4:607-18.

8. Tam A, Sin DD. Pathobiologic mechanisms of chronic obstructive pulmonary disease.Med Clin North Am 2012;96:681-98.

9. Kent BD, Mitchell PD, McNicholas WT. Hypoxemia in patients with COPD: cause, effects, and disease progression. Int $\mathrm{J}$ Chron Obstruct Pulmon Dis 2011;6:199-208.

10. Barnes PJ, Celli BR. Systemic manifestations and comorbidities of COPD. Eur Respir J 2009;33:1165-85.

11. Foster TS, Miller JD, Marton JP, Caloyeras JP, Russell MW, Menzin J. Assessment of the economic burden of COPD in the U.S.: a review and synthesis of the literature. COPD 2006;3:211-8.

12. Cavaillès A, Brinchault-Rabin G, Dixmier A, Goupil F, Gut-Gobert C, Marchand-Adam S, et al. Comorbidities of COPD. Eur Respir Rev 2013;22:454-75.

13. Anthonisen NR, Connett JE, Enright PL, Manfreda J. Hospitalizations and mortality in the Lung Health Study. Am J Respir Crit Care Med 2002;166:333-9.

14. Laratta $C R$, van Eeden $S$. Acute exacerbation of chronic obstructive pulmonary disease: cardiovascular links. Biomed Res Int 2014;2014:528789.

15. Seeger W, Adir Y, Barberà JA, Champion H, Coghlan JG, Cottin V, et al. Pulmonary hypertension in chronic lung diseases. J Am Coll Cardiol 2013;62:D109-16.

16. Evora PR, Evora PM, Capellini VK, Celotto AC. Mitral stenosis acute pulmonary edema and rheumatic fever pneumonitis: a hypothesis to an old enigma. Int $\mathrm{J}$ Cardiol 2011;151:365-6.

17. Woolley K, Stark P. Pulmonary parenchymal manifestations of mitral valve disease. Radiographics 1999;19:965-72. 
18. Chatterji RS, Panda BN, Tewari SC, Rao KS. Lung function in mitral stenosis. J Assoc Physicians India 2000;48:976-80.

19. Palaniswamy C, Selvaraj DR, Guleria R, Mohan A, Narang R. Airway hyper-reactivity in rheumatic mitral stenosis improves after balloon valvotomy. Ther Adv Cardiovasc Dis 2009;3:423-7.

20. Cieslewicz G, Juszczyk G, Foremny J, Hamelmann E, Religa Z, Zembala M, et al. Inhaled corticosteroid improves bronchial reactivity and decreases symptoms in patients with mitral stenosis. Chest 1998;114:1070-4.

21. Edrich T, Sadovnikoff N. Anesthesia for patients with severe chronic obstructive pulmonary disease. Curr Opin Anaesthesiol 2010;23:18-24.

22. Spieth PM, Güldner A, de Abreu MG. Chronic obstructive pulmonary disease. Curr Opin Anaesthesiol 2012;25:24-9. 